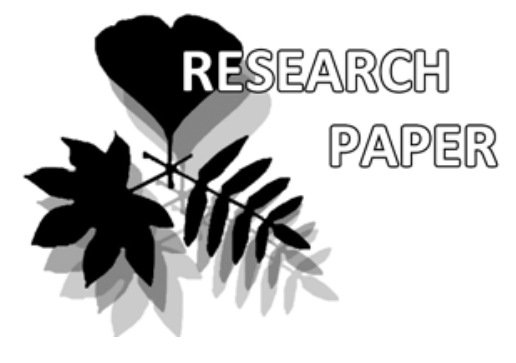

Dina I. Nazimova ${ }^{1, *}$

e-mail: inpol@mail.ru

Dilshad M. Danilina ${ }^{1}$

e-mail: dismailova@mail.ru

Nikolay V. Stepanov ${ }^{2}$

e-mail: stepanov-nik@mail.ru

${ }^{1}$ V.N. Sukachev Institute of Forest SB RAS Krasnoyarsk, Russia

${ }^{2}$ Siberian Federal University

Krasnoyarsk, Russia

* corresponding author

Manuscript received: 25.10.2013

Review completed: 21.11.2013

Secondary review completed: 16.03.2014

Accepted for publication: 25.03.2014

\section{Biodiversity of Rain-Barrier Forest Ecosystems of the Sayan Mountains}

\author{
Dina I. Nazimova ${ }^{1 *}$, Dilshad M. Danilina ${ }^{1}$, Nikolay V. Stepanov ${ }^{2}$
}

\begin{abstract}
A B S T R A C T
Mixed conifer-broadleaved forests with tall herbs composed of Abies sibirica, Pinus sibirica and Populus tremula, also known as "Chern forests" in Russia, represent a separate class of subboreal (hemiboreal) ecosystems in the Altai-Sayan Ecoregion. Their structure is not that of boreal Siberian taiga, and resembles some features of subnemoral dark coniferous forests of the Far East. Recent studies by the authors confirm relict and original features of these Chern forest types, their synusial structure and ancient floristic links with Far Eastern mixed coniferousbroadleaved forests. On the other hand, the Chern forests may be classified as a part of unique rain-barrier boreal orobiome, which is represented only in perhumid bioclimatic provinces of the South Siberian mountains and is composed of a complex of altitudinal belts: mixed dark coniferous forests with a mix of broadleaved trees (Chern), perhumid dark taiga, and subalpine dark forests and woodlands. These forest types are important for bioclimatic classification and mapping of mountain vegetation.
\end{abstract}

Keywords

Chern forests, rain-barrier ecosystems, ordination, classification, life forms, nemoral relics, ancient floristic links, Sayan, Far East

\section{P E 3 Ю M E}

Назимова А.И., Аанилина А.М., Степанов Н.В. Биоразнообразие барьерно-дожАевых месных экосистем Саян

Смешанные хвойные и хвойно-широколиственные леса с высокотравным покровом, с доминированием Abies sibirica, Pinus sibirica и Populus tremula, известные в России как черневые леса, представ яют особый класс суббореальных (гемибореальных) экосистем А^тае-Саянского Экорегиона. Их структура не типична А^я бореальной сибирской тайги и некоторыми чертами напоминает субнеморацьные темнохвойные меса Аальнего Востока. Последние исследования авторов подтверждают реликтовый и самобытный характер черневых месов и их синузиальной структуры, а также Аревние флористические связи со смешанными темнохвойно-широколиственными месами Аальнего Востока. С Аругой стороны, при обобщенной классификации черневые меса могут быть отнесены к уникальному оробиому барьерно-дожАевых Аесов, который представлен только в избыточно-влажных (пергумидных) биоклиматических провинциях гор Южной Сибири и слагается спектром высотно-поясных комплексов: черневые смешанные и

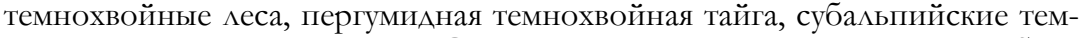
нохвойные леса и редколесья. Эти растительные единицы важны Аля биокАиматической классификации и картирования горной растительности и горных экосистем.

ключевые слова

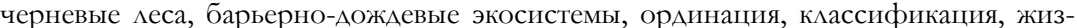
ненные формы, неморальные реликты, Аревние флористические связи, Саяны, Аальний Восток

Nomenclature: vascular plant names are given after Cherepanov (1995), bryophyte names - after Ignatov et al. (2006) and lichen names - after Urbanavichus (2010)

\section{INTRODUCTION}

Mountain forests of the Altai-Sayan Ecoregion (ASE), well-known as the center of biodiversity in Eurasia, are made up of a number of altitudinal zones (or belts). In the Russian literature they are known as altitudinal belt complexes (ABC) of forest types. Their spectra (spectra of $A B C$ ) on the slopes of ridges depend on climatic regime and may serve as distinctive indicators to differentiate among largescale bioclimatic provinces (Smagin et al. 1980, Polikarpov et al. 1986). Mixed conifer and conifer-broadleaved forests with tall herbs composed of Abies sibirica, Pinus sibirica and Populus tremula, also known in Russia as "Chern" (from the 
Russian 'чёрный', = black), represent a peculiar class of ecosystems that occur only on the windward slopes of ASE in gentle mountain relief (300-900 m). They are interesting in aspects of their biodiversity, classification of orobiomes, and their richer regional structural type diversity, such as ABC and formations (see for details Polikarpov et al. 1986, Tchebakova 1983, 2006). The problems of Chern forests genesis, floristic links with European and Far Eastern mountain forests are infrequently documented (Stepanov1994a, Ermakov 1995, 2006, Kamelin 1998, Stepanov et al. 2011).

The purpose of this paper is to describe the regional ecosystems of the Sayan Chern dark coniferous and mixed forests, their geography, their place in climatic ordination schemes, some features of physiognomy, synusial structure and biodiversity, in comparison with some similar mountain ecosystems of the Far East.

The Chern forests of the Altai-Sayan mountains are known from the beginning of the 20th Century as a specific class of mixed dark-coniferous and deciduous broad-leaved forests with great biodiversity and some relic features in their composition (Baranov \& Smirnov 1931, Shumilova 1962, Nazimova 1975, Gudoshnikov 1986, Polikarpov et al. 1986, Isachenko et al. 1988, Stepanov 1994a, Ismailova \& Nazimova 2010). They form a clearly recognized altitudinal belt of Siberian fir, Siberian pine and fir-aspen forests in low mountains of the northern and western slopes of the Altai, West and East Sayans and Salair-Kuznetsky mountains, where the climate is humid and perhumid (according to Holdridge 1967).

Along with the "Chern forest" a class of "Chern taiga" was suggested (Baranov \& Smirnov 1931), which occurs in even wetter conditions than "Chern forest", and located at the higher elevations. Here it is composed only of dark taiga species: Abies sibirica, Pinus subirica, locally Picea obovata, while the aspen, Populus tremula, become less significant tree species in colder and wetter climate. These two formations (Chern forest and Chern dark taiga) are similar in some features of their structure, and may be considered together as a part of the humidity dependent boreal coniferous forests with specific flora and soils (Krestov et al. 2010). We try to avoid the term "Chern taiga" to simplify classification but in some aspects of forest management it is reasonable to distinguish it.

\section{METHODS}

The biodiversity of Chern forest with dominance of Pinus sibirica and Abies sibirica have been studied in the West Sayan and East Sayan mountains $\left(55^{\circ} 45^{\prime}-52^{\circ} 50^{\prime} \mathrm{N}\right.$, $\left.91^{\circ}-93^{\circ} \mathrm{E}\right)$ by forest ecologists of the Institute of Forest since 1961, especially from 2005 to 2012, with participation of Siberian Federal University botanists, entomologists and paleogeographers (Stepanov et al. 2011).

Our studies included field works in the primary and secondary forest stands on permanent and temporary plots (Fig. 1) using geobotanical and ecological methods (Smagin et al. 1980, Polikarpov et al. 1986, Isachenko et al. 1988), and methods and materials of forest inventory in the Tanzybey forestry area (480 000 ha). Using field methods and materials we created the original database (DB) on a moun- tain profile-transect $50 \mathrm{~km}$ long (350-1500 m a.s.l.) and produced a series of maps 1:50 000 scale on the territory of Bolshoy and Maliy Kebezh river basin (approximaly $50000 \mathrm{ha}$ ). Long-term researches continue at the Ermakovskii forest station of Institute of Forest of the Siberian Branch of the Russian Academy of Sciences (IF SB RAS) and contribute to the regional $\mathrm{DB}$ on the mountain forest formations, with special attention to primary and secondary (after timber removal) successions.

Special section of the Information system are devoted to the Chern mountain forest types, including the data from forest inventories in 1970 and 1995, data on species diversity, field data, remote sensing data, climate parameters, soil characteristics and others. The DB on 560 vascular species forming the Chern forest communities contains original data on their occurrence, and on the assignment of species to taxonomic, geographical, zonal, biomorphic and ecological groups.

\section{RES U LTS}

Figure 1 shows the distribution dark coniferous forests on the windward slopes of ASE. The Chern forest ABC (300-800-1000 $\mathrm{m}$ a.s.l.) occupies only a part of the perhumid climatic facies, approximately 1 million ha in Sayan provinces and 2 millions ha more in northwestern part of ASE. The main differences between forest provinces are a lesser degree of disturbance and a greater proportion of Siberian pine in old Chern forest ecosystems in the middle ranges of the Sayans.

Figure 2 shows the distribution of main bioclimatic zones (correspond to orobiomes) in the climatic spaces of warmth and precipitation: tundra, open woodland, dark coniferous taiga (Pinus sibirica, Abies sibirica, Picea obovata), light coniferous taiga (Larix sibirica, Pinus sylvestris), mixed subtaiga (light coniferous and small-leaved deciduous forests of Betula pendula and Populus tremula) with herbs and grasses but no mosses, forest-steppe and steppe. The most of the Altai-Sayan mountain system is situated in steppe zonal biome or forest-steppe zonoecotone, while the boreal forest, open woodlands and mountain tundra appear as orobiomes due to mountain relief that change the macroclimate. In this context, the classification of mountain bioclimatic facies, zones and belt complexes corresponds in general to the classification of terrestrial ecosystems and zonobiomes of Walter \& Box (1976) and correlates with the life zones classification of Holdridge (1967). Climatic ordination allows to correlate each individual $\mathrm{ABC}$ with the larger categories, bioclimatic zones, orobiomes and climatic facies.

The unique subnemoral Chern forests of Abies sibirica, Pinus sibirica and Populus tremula, located on the windward slopes of Altai, Salair, Kuznetsky Alatau and Sayan mountains, takes its place in the system as the wettest and warmest. At the lower elevations, the Chern forests contact the mixed light coniferous forest zone (or subtaiga) and foreststeppe; the latter forms the basal vegetation of $\mathrm{ABC}$ spectra on the windward slopes of the Sayan Mountains. The upper elevations are occupied by superhumid dark taiga with Abies sibirica and Pinus sibirica (850-1300 $\mathrm{m}$ a.s.l.); above this is subalpine open woodlands and meadows (1300-1600 m 


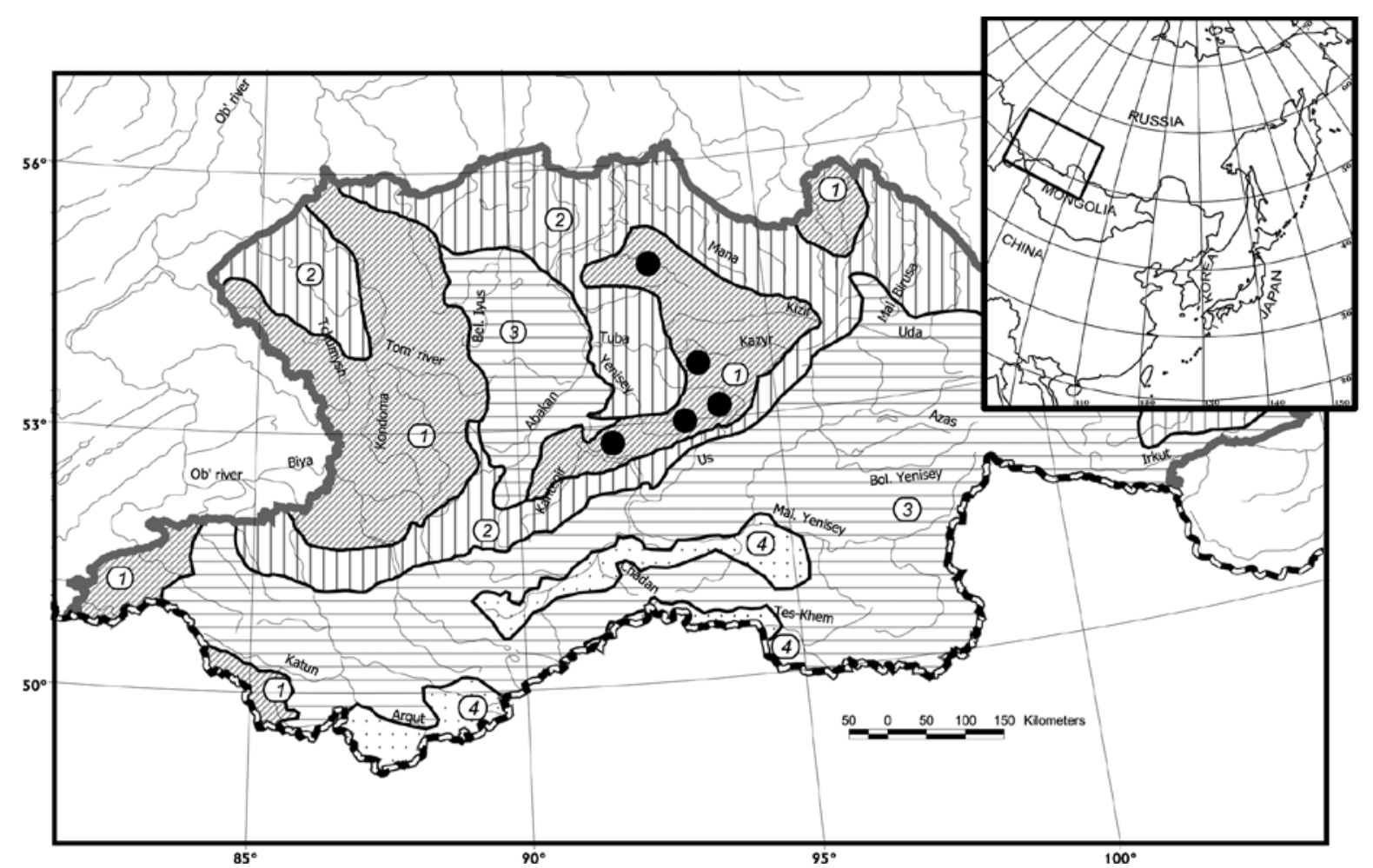

Figure 1 Schematic map of climatic facies of Altai-Sayan mountain forests and study plots (black circles). Each of 4 facies takes particular sector of climatic space and differs in forest types composition and biodiversity: 1) perhumid cyclonic taiga and Chern forest ecosystems with dominance of the conifers (Abies sibirica) with tall herbs and ferns; 2 ) humid cyclonic taiga ecosystems with dominance of dark coniferous species (Pinus sibirica) in spectrum of ABC, mainly with well developed moss cover and dwarf shrubs; 3) moderate humid or semihumid taiga and forest-steppe ecosystems, with dominance of larch (Larix sibirica) with herbs and dwarf shrubs; in high mountains Siberian pine (Pinus sibirica) dominates; 4) semiarid facies with dominance of steppe in ABC spectra and a reduction of Larch forest (Larix sibirica) belt

a.s.l.); and above this is mountain tundra (above 1500$1600 \mathrm{~m}$ a.s.l.).

The system on Fig. 2 allows to recognize the place of Chern forest altitudinal belt in the Altai-Sayan mountain zone system, and in bioclimatic sector system. The latter includes superhumid, humid, semihumid and semiarid climatic facies (Polikarpov et al. 1986). The dashed arrows on Fig. 2 indicate the spectra of $\mathrm{ABC}$ in each bioclimatic sector (or climatic facies).

\section{Climatic parameters of the Chern forest}

According to DB on climate and vegetation of West Sayan, some climatic indices of the Chern $\mathrm{ABC}$ have values similar to these of some remote dark coniferous subnemoral ecosystems of the Far East and Europe.

We compared the West-Sayan Chern forest with: 1. Deciduous broadleaved-dark coniferous forests of the Far East mountains and 2. Deciduous broadleaved-coniferous forests of the European part of Russia. We calculated the following climatic indices: average annual temperature amplitude (A); accumulated temperatures for the active growth period (ST);

Figure 2 Climatic ordination of altitudinal belt complexes (and their spectra) and place of chern forest in general system of bioclimatic zonality. Spectra of ABC: A - perhumid cyclonic, B - humid cyclonic, C - semihumid anticyclonic, D - semiarid anticyclonic. Main orobiomes: Mountain tundra, Mountain boreal forest, Mountain steppe; Classes of ABC: 1 - tundra and high mountain open woodlands, 2 - larch taiga, 3 - dark conifer taiga and subtaiga, 4 - forest-steppe, 5 - Chern forest annual precipitation $(\mathrm{P})$; average relative humidity in July at 1 p.m. (H); hydrothermal coefficient and growing season (days).

Shumilova (1962) labels Chern forests as "taiga subnemorosa", thus emphasizing its similarity to the European "Nemorosa", as well as its uniqueness in Siberia and transition to the mixed nemoral type. Ermakov (1995) relates Chern forest vegetation to the West European class QuercoFagetea. He assigns Chern forests of Siberia to the separate suborder Fagetatia sylvaticae, shady deciduous forests.

Compared to the Far Eastern forests, the dark Chern forests of West Sayan are poorer in tree and shrub species

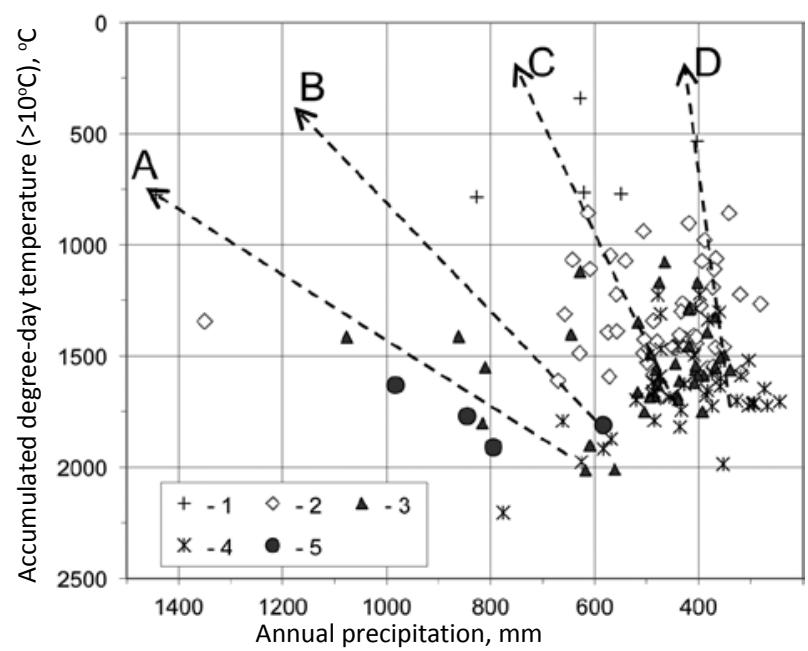


Table 1. Some Indices of climate in different regions of Russia with classes of mixed dark-coniferous - deciduous (broadleaved) forest ecosystems

\begin{tabular}{|c|c|c|c|c|c|c|}
\hline Classes & $\begin{array}{l}\text { Average } \\
\text { annual tem- } \\
\text { perature am- } \\
\text { plitude, }{ }^{\circ} \mathrm{C}\end{array}$ & $\begin{array}{c}\text { Accumulated } \\
\text { temperatures } \\
\text { for the growth } \\
\text { period }\left(>10^{\circ} \mathrm{C}\right)\end{array}$ & $\begin{array}{l}\text { Annual } \\
\text { precipita- } \\
\text { tion, mm }\end{array}$ & $\begin{array}{l}\text { Average rela- } \\
\text { tive humid- } \\
\text { ity in July at } \\
1 \text { p.m., } \%\end{array}$ & $\begin{array}{c}\text { Hydrothermal } \\
\text { coefficient } \\
\text { for the period } \\
\text { with } T>+10^{\circ}\end{array}$ & $\begin{array}{l}\text { Growing } \\
\text { season, } \\
\text { months }\end{array}$ \\
\hline $\begin{array}{l}\text { Chern forests of West Sayan } \\
\text { at } 350-850 \mathrm{~m} \text { a.s.l. (coniferous } \\
\text { and mixed coniferous-broad- } \\
\text { leaved with deciduous trees) }\end{array}$ & $30-35$ & $1200-1800$ & $500-1200$ & $60-70$ & $1,6-3,0$ & $5,0-4,5$ \\
\hline $\begin{array}{l}\text { Mixed coniferous-broadleaved } \\
\text { forests of the European part } \\
\text { of Russia (Picea abies, Pinus } \\
\text { sylvestris, Tilia cordata, Quercus } \\
\text { robur) }\end{array}$ & $20-34$ & $1600-2400$ & $\begin{array}{l}500-600 \\
(\max 800)\end{array}$ & $50-70$ & $1,2-2,0$ & $6,0-4,5$ \\
\hline $\begin{array}{l}\text { Coniferous (Pinus koraiensis, } \\
\text { Abies nephrolepis, Picea ajanensis) } \\
\text { and mixed coniferous-broad- } \\
\text { leaved forests of the Far Eas- } \\
\text { tern mountains (northern geo- } \\
\text { graphical facies of temperate } \\
\text { forests) }\end{array}$ & $30-42$ & $1600-2200$ & $600-1000$ & $65-80$ & $1,6-2,6$ & $5,5-4,5$ \\
\hline
\end{tabular}

number and much more humid and colder than mixed dark coniferous forests of Sikhote-Alin. The latter are composed of Abies nephrolepis, Picea ajanensis and the nemoral tree species Pinus koraiensis with a mixture of broadleaved deciduous species. Species richness in tree and shrub layers is 10-12 times greater in Sikhote-Alin mixed mountain forest. But they are similar in type of soils (brown soils and lessivage processes are usual in both cases). There is no frost in the soils of the Chern forests that would promote a great number of ephemerals and a well developed synusiae of nemoral species. Due to winter monsoon, the continentality of climate in the east slope of the Sikhote-Alin mountains and Malyi Khingan ridge is not less than in Chern belt of Sayan mountains. Many nemoral species of Far Eastern trees, shrubs, herbs and grasses are more tolerant of frosts than nemoral species of herbs and shrubs in Sayan Chern forests. It is worth mentioning here that deep snow cover plays a protective role and remains an important factor of stability of Chern forests in Sayan refugia throughout the Quaternary period.

\section{DISCUSSION}

The main question addressed in the discussion is what factors determine the occurrence of Chern coniferous and mixed forests in the center of Asian continent?

\section{History}

Chern forests were formed during the Quaternary in mountain refugia of Tertiary nemoral flora located in several Sayan and Altai regions, which served and remain as the main centers of autochthonous development of peculiar south Siberian mesic flora. Despite the fact that the broadleaved tree species are almost extinct, the nemoral herbaceous species have survived and adapted to the current environment under the canopy of a mixed forest of aspen, fir and Siberian pine. The basins of Maliy and Bolshoy Kebedz Rivers represent one of the refugia in low and middle mountains of Kulumys Mountain Range. It is the most pro- minent among the other local refugia of the Altai-Sayan ecoregion in richness of nemoral relic herbs, bryophytes, lichens, insects, fungi and some other components of biota. The other known refugia of nemoral flora are situated in the Northeast Altai (near Teletskoe Lake), in the SalairKuznetsk province (Kuzedeev Island with isolated population of Tilia sibirica), in the West Altai (the Kholzun ridge). The region of Modzarski Lakes in the piedmont of East Sayan is the nearest to the West Sayan refugium that had close ties in the past.

\section{Climatic features}

The regimes of warmth and moisture were more or less suitable to keep and preserve nemoral complex of biota from freezing and drying. During the 20th Century the climate parameters were more or less adequate to survival of temperate species (Anonymous 1966, 1967).

Accumulated degree-day temperatures $\left(>10^{\circ} \mathrm{C}\right)$ are rather high, compared with Siberian boreal taiga and vary from 1400 to $1800^{\circ} \mathrm{C}$. Precipitation ranges from 700 to 1200 (1500) mm/year, being much greater than in Siberian taiga. Snow cover is thick and remains on the ground 4 to 4.5 months, so the soils do not freeze in winter.

Wildfires are rare in the Chern forest ABC. Windstorms and windfalls mostly affect forest structure. As a result, uneven-aged virgin forests have been formed on the mountain slopes long ago and exist during period of lifespans of several generations of Siberian pine.

\section{Plant community structure}

The primary Chern forests are not dense; there are many gaps in the tree layer. The forests are composed of different-aged trees of Abies sibirica, old and mature trees of Pinus sibirica and a mixture of broadleaved trees of Populus tremula, Betula pendula, B. platyphylla and B. pubescens. The herb layer is well-developed and species-rich.

In contrast to the northwestern provinces of ASE, the role of Picea obovata in the Sayan Chern forest is insignifi- 
cant. The aspen and mixed fir-aspen-birch stands are mainly the secondary formations in the Chern forest $\mathrm{ABC}$ and do not extend above the elevation of $900 \mathrm{~m}$ a.s.l. On the lower border of the Chern belt (300-400 $\mathrm{m}$ a.s.l.), in contact with pine-birch forest types with well-developed herb layers (subtaiga $\mathrm{ABC}$ ), a narrow band of Chern aspen stands is formed and survived during last 100-200 years, though dark coniferous trees enter the forest from time to time in some local sites. Perhaps, it is reasonable to consider this aspen formation as a climatic climax, but it is difficult to detect the borders of aspen belt as a separate unit (ABC), due to its narrow and interrupted distribution in geographical space.

Large parts of Chern dark-coniferous forests (mainly pine-fir stands) are disturbed by logging. But nevertheless the territory of Maliy Kebedz with Chern Siberian pine and fir massifs remains as a biodiversity reservoir of Chern forests since 1960 s and serves as an object of great scientific interest.

Tree layer (heights range from 30 to $32 \mathrm{~m}$ and reach $42 \mathrm{~m}$ ) is composed of Pinus sibirica (30-80\%) and Abies sibirica (20-70\% of total stock volume). Birch and aspen also occur as secondary trees and occupy small gaps after windfalls and other disturbances. The mixed dark Chern forest stands, as noted above, are simple in structure and may not always form two layers because of their scattered structure.

The low trees and shrubs (Daphne mezereum, Padus avium, Ribes hispidulum, R. nigrum, Rubus idaeus, Salix caprea, Sambucus sibirica, Spiraea chamaedrypholia, S. media, Viburnum opulus, and others) form a mosaic layer, especially dense after disturbances in the canopy gaps at early succession stages.

Tall herb layer (1.0-1.8 $\mathrm{m}$ in height and $80-100 \%$ cover), the main physiognomic marker of Chern forests, is formed by tall ferns, herbs and graminoids: Diplazium sibiricum, Athyrium filix-femina, Dryopteris carthusiana, D. expansa, D. filix-mas, Matteuccia struthiopteris, Polystichum braunii, Aconitum septentrionale, Angelica sylvestris, Cacalia hastata, Cirsium belenioides, Geranium krylovii, Milium effusum, Veratrum lobelianum, and others. More than 40 species of herbs are found on the plot 20 by $20 \mathrm{~m}$. Tall forbs and ferns form rich mixed synusiae in the tall herb layer. Much of them can be classified in the boreo-nemoral group of species.

Well developed synusiae of nemoral relic species (Anemone baicalensis, Brunnera sibirica, Cruciata krylovii, Festuca altissima, F. gigantea, Galium odoratum, Polystichum braunii and some others) add to the specific composition of plant communities. Nemoral herb synusiae occupy $30-80 \%$ of total ground cover.

An important characteristic of Chern forests is the presence of synusiae spring (April-May) ephemerals: Anemone altaica, A. jenisseensis, A. reflexa, Corydalis bracteata, and, locally, Erythronium sajanense (Stepanov \& Stassova 2011).

In addition, the synusiae of Gymnocarpium dryopteris, Maianthemum bifolium and Oxalis acetosella are developed on old fallen trunks, branches and roots and directly on the ground surfaces, together with Circaea alpina, Impatiens noli-tangere and the hygrophyllous mosses Mnium spp., Bryum spp. and others. Many of them are also nemoral species.

Along with large ferns, tall forbs and other groups of species mentioned above, a group of swamp herbs and species from less common ecological groups may occur also in the Chern forest.

We recognized 14 ecological groups (EG) of herbs characteristic of coniferous Chern formations (Nazimova 1975, Ismailova \& Nazimova 2010).

\section{Mosses}

One of the Chern forest peculiarities differing it from boreal Siberian taiga is the scarcity or absence of boreal mosses (Dicranum spp., Hylocomium splendens, Pleurozium shreberi, Rhytidiadelphus trquetrus, R. squarrosus, ets.), which avoid dense herb patches and occur on the old dead trunks and roots. On the contrary, great diversity of species from family Mniaceae are concentrated in Chern forests on different substrates, including ground surface. This reflects a nemoral character of the bryoflora (Gudoshnikov 1986). Although this flora is rich in species diversity, the moss layer is thin and imperceptible. Synusiae of hygrophyllous mosses (Cirriphyllum piliferum, Eurbynchium angustirete, Plagiomnium cuspidatum, P. confertidens, Rhodobrium roseum, Sanionia uncinata) cover $20-70 \%$ of ground cover. Such species as Thamnobryum neckeroides and Eurynchium angustirete form synusiae in the unique linden forest communities (Tilia sibirica) of "Kuzedeevskiy Island". The specific features of the Chern forest lichen complex will be characterized below.

\section{Endemics and relicts}

A large number of endemic and relic herbs characterize the unique Sayan Chern refugium and serve to differentiate it from other refugia, such as Teletskii (near Teletskoe Lake in Altai), "Kuzedeevskiy island" and others (Polojii \& Krapivkina 1985).

Most nemoral herbs and some nemoral shrubs occurring in the Chern forests (Brunnera sibirica, Cruciata krylovii, Daphne mezereum, Festuca altissima, Frangula alnus, Galium odoratum and Stachys sylvatica) belong to the European and/ or Mediterranean floras. However, some Tertiary relics (Anemone baicalensis, Menispermum daburicum and Waldsteinia tansybeica (Stepanov 1994b) are of East Asian origin (Fig. 3).

Recently, several new for the science taxa, such as Asplenium trichomanes subsp. kulumyssiense (Stepanov 1994c), Waldsteinia tanzybeica (Stepanov et al. 2011, Red book... 2012) were described as evidently relic and endemic.

Some common nemoral mosses (Cirriphyllum piliferum, Eurbynchium angustirete, Thamnobryum neckeroides) and epiphytic lichens (Leptogium burnetiae, Lobaria retigera, L. scrobiculata, Nephromopsis laureri, Pannaria conoplea, Parmelina quercina, P. tiliacea, Sticta limbata and others) are found in different sites in Chern forests of Sayan Mountain (Fig. 4).

Siberian forest ecologists (Smagin et al. 1980) threat the Chern forest and Chern taiga as different but similar classes of forest ecosystems, which usually co-occur on windward slopes of mountains in the Chern forest $\mathrm{ABC}$ between the elevations of 300 and 850 (900) m. a.s.l. Above this level the structure of plant communities changes sharply and becomes similar to that of typical boreal taiga. Due to superhumid climate, most of them are composed only of Abies sibirica dense stands of site index class IV-V (poor site quality), with herb and moss cover. Siberian pine is almost 
absent at 900-1300 m a.s.l. Only boreal species of shrubs, such as Lonicera altaica, Ribes hispidulum, Sorbus sibirica, herbs: Calamagrostis obtusata, Cerastium pauciflorum, Diplazium sibiricum, Dryopteris dilatata, D. expansa, Linnaea borealis, Lycopodium annotinum, Oxalis acetosella, Stellaria bungeana, Viola biflora, and mosses: Dicranum scoparium, D. fuscescens, Hylocomium splendens, Pleurozium schreberi, Rhytidiadelphus triquetrus, form well-developed layers. Among dominants, Vaccinium myrtillus and Bergenia crassifolia occur more than any other species on rocks, screes, steep slopes with shallow soils.

Table 2 shows the distinctive differences between two classes of mountain coniferous forests: Chern forest and perhumid dark taiga. This table includes climate, forestforming tree species; site index classes, main synusiae of undergrowth and associated insect population. In both forest types there are a great number of nemoral species of mosses and lichens in the communities. The distribution of lichens and mosses is not much changed within a transition zone between the elevation belts. The most ancient groups of species adapted to specific microsites are able to find suitable niches in the mountains in a wide range of sites up to elevation of $1300 \mathrm{~m}$ a.s.l., in the subalpine belt.

\section{Chern forest and rain-barrier forest as bioclimatic subdivisions at different levels}

The climatic regime, soil types, structure and seasonal functioning of Chern forests allow to qualify them as occurring in the warmest part of boreal forest ecosystems, under a perhumid climate. Above the Chern forest the belt of taiga dominated by Siberian fir is formed as other part of a rain-barrier forest complex, with cooler and wetter climate ( $\mathrm{ST}=1200-800^{\circ}, \mathrm{P}=1000-1550 \mathrm{~mm}, \mathrm{PPE}=0.2-0.3$ ). Both these ABC's in combination with subalpine open woodlands on the tops of ridges together form the whole spectrum of rain-barrier forest ecosystems on the windward slopes of the West and East Sayans. The rain-barrier forest ecosystems can be identitied by the dominance of conifers in a wide range of altitudes (350-1500 $\mathrm{m}$ a.s.l.) and correspond to rain-barrier landscapes in sense of Isachenko et al. (1988). Their history and floristic origin were clarified

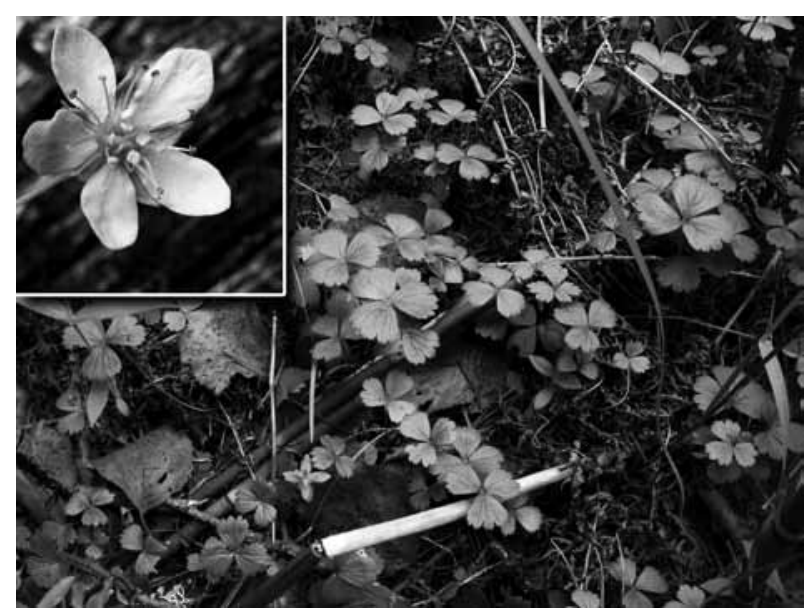

Figure 3 Waldsteinia tanzybeica in the chern fir forest at elevation of $500 \mathrm{~m}$ a.s.l. in the past few years as our DB on biodiversity and climate was created and widened. But the first mention of nemoral flora in Sayan refugia near the Enisey River were found in the Russian literature at the beginning of the 20th Century (the publications of Krylov, Kuminova, Cherepnin, Gudoshnikov; see Stepanov (1994a) for details).

The first climatological calculations for the boundaries of the $\mathrm{ABC}$ on the West-Sayan profile-transect were made in 1960-1970s and emerged from the field experimental data (Tchebakova 1983, 2006, Polikarpov et al. 1986). Different ordination schemes showed climate-vegetation relations in the region and reflected the leading role of climate humidity for the spectra of ABC (Fig. 2).

Floristic analysis of the collected database on rain forests biodiversity ( 847 vascular species have been recorded in Chern forest) has led to some unexpected results. Comparison of the species number with Eastern and Western links shows that the number of species common with the East Asia is 558 (66\%), and species common with the West (European part of Russia) - 540 (64\%). The same ratio is found if we compare the species with strictly Western links $(14 \%)$, and species with strictly Eastern links (16\%). The Eastern species are represented by quite a complicated chorological structure pointing to an ancient and continuous history. At the same time, all the species with strictly western links are represented by a separate, more or less homogenous, chorological group of Eurosiberian species. This emphasises their relatively recent arriving.

The number of autochtonous species is $266(31 \%)$. This group is also heterogenous and complex. Autochtonous species are fundamental to the Chern rain forest formation.

Among other plants (bryophutes, fungi and lichens), there were relic plants of ancient (Tertiary) origin having either an endemic area or a wider geography (Stepanov et al. 2011), and a narrow relic area in Siberia connected only with humidity-dependent forests (Krestov et al. 2010).

Composition of life forms (Fig. 5) with an increased role for cryptophytes and with a decreased role for chamaephytes confirms the conclusion of Chern forest flora

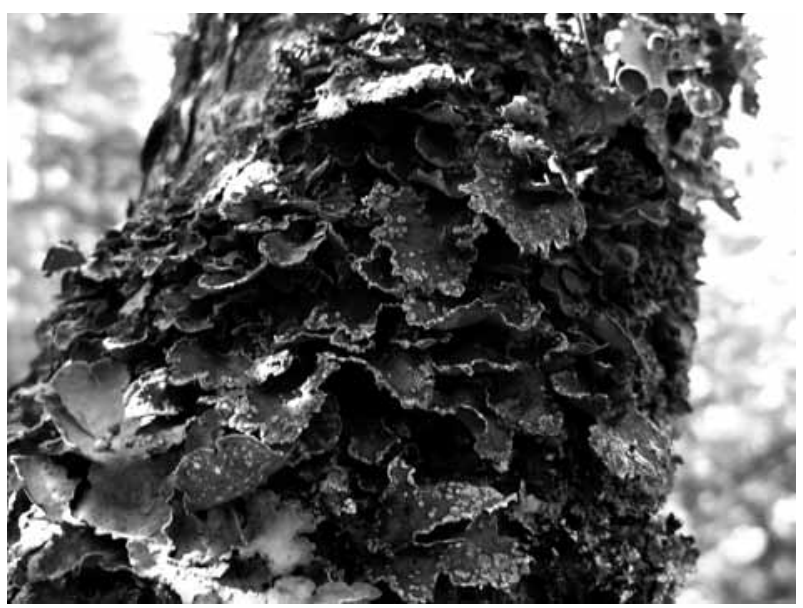

Figure 4 Synusia of epiphyte lichens (Sticta limbata, S. wrightii and others) on the bark of Sorbus sibirica in the Chern forest at elevation of $800 \mathrm{~m}$ a.s.l. 
Table 2. The main features of biogeoclimatic subzones (and ABC) on the windward slopes of Sayan mountains (by Nazimova et al. 2002)

\begin{tabular}{|c|c|c|c|}
\hline $\begin{array}{l}\text { Biogeoclimatic subzone; } \\
\text { Climate: ST } 10^{\circ}\left({ }^{\circ} \mathrm{C}\right) \\
\text { Annual precipitation } \\
(\mathrm{mm})\end{array}$ & $\begin{array}{l}\text { Forest } \\
\text { dominants; } \\
\text { site index } \\
\text { class }\end{array}$ & Main synuziae of understorey, life form composition & $\begin{array}{l}\text { Fire dangerous period, days; } \\
\text { postfire successions }\end{array}$ \\
\hline $\begin{array}{l}\text { Low Mountain Chern } \\
\text { Forest } \\
1650-1150 ; 560-1200\end{array}$ & \begin{tabular}{|l|} 
Populus tre- \\
mula, Abies \\
sibirica, Pinus \\
sibirica, Betula \\
pendula; I-III
\end{tabular} & $\begin{array}{l}\text { Dominance of boreo-nemoral herbs (Athyrium filix-femina, } \\
\text { Mateuccia strutbiopteris, Dryopteris carthusiana, D. expansa), a } \\
\text { mix of relic nemoral species, forming synusiae in herb and } \\
\text { moss layers. Rich biodiversity. Shrubs: Padus avium, Vibur- } \\
\text { num opulus, Spirea spp., Sambucus sibirica, Daphne mezereum. }\end{array}$ & $\begin{array}{l}5-20 \text {; after logging }- \text { tall herbs, } \\
\text { grasses and ferns dominance. At } \\
\text { the first stages - aspen and fir } \\
\text { prevale in successions }\end{array}$ \\
\hline $\begin{array}{l}\text { Mountain Coniferous } \\
\text { Perhumid Taiga } \\
\text { 1300-600; } 900-1300 \\
(1550)\end{array}$ & $\begin{array}{l}\text { Abies sibirica, } \\
\text { Pinus sibirica; } \\
\text { II-IV }\end{array}$ & $\begin{array}{l}\text { Dominance of boreal herbs (Calamagrostis obtusata, C. lang- } \\
\text { sdorffi, Dryopteris dilatata, Gymnocarpium dryopteris) dwarf- } \\
\text { shrubs (Vaccinium myrtillus). Nemoral herb species number } \\
\text { reduce; biodiversity decrease. Moss cover is well developed, } \\
\text { with mosses typical for taiga ecosystems: Hylocomium splen- } \\
\text { dens, Rhytidiadelphus triquetrus, Pleurozium shreberi, Dicranum, } \\
\text { Polytrichum communis }\end{array}$ & $\begin{array}{l}0-30 \text {; short-termed birch, pine, } \\
\text { aspen stands are usual }\end{array}$ \\
\hline
\end{tabular}

antiquity and points to sister-species connections to the nemoral flora of the mixed coniferous-deciduous hardwood forests. Fig. 5 shows that the chern and broadleaved forests are similar most of all in general life forms by proportion of life forms in the spectra of zonal biomes (Agakhanyants 1986). The role of chamephytes is essentialy less in the Chern forest while the role of cryptophytes reachs high values - these features make the Chern forest flora spectrum unique. The general role of phanerophytes is unusually low that allows to conclude that tree species in Tertiary period had undergone to destructive influence of cooler climate and were substituted by more tolerant competitors. Probably, the winter frosts were just that limiting factor, which impoverished composition of forest-forming species in the periods of glaciation. Competition by more tolerant tree species appeared to be an important factor in the processes of impoverishing the proportion of tree species in Chern forest flora. At the same time, small shrubs and herbs and perhaps many of soil biota species have survived in the unfavorable conditions due to deep snow.

A general analysis of the subnemoral species complex in the North-Asian hemiboreal forests (187 species) was made by Ermakov (2006). The West Sayan subnemoral complex includes 544 species, which were analyzed for floristic relations with the floras of Eastern and Western adjacent areas. The main groups of species: nemoral forest, taiga,

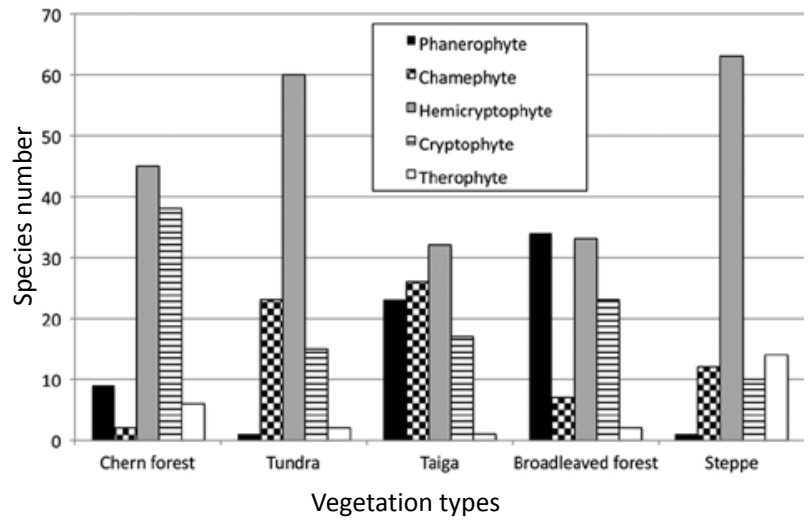

Figure 5 Raunkier's life forms spectrum of the rain-barrier forests in West Sayan coniferous chern forest and perhumid taiga, between 350 and $1300 \mathrm{~m}$ a.s.l.

high-mountain vegetation, light conifer forest (in other words hemiboreal) appeared to be practically the same in both floras (Table 3).

The West Sayan subnemoral flora (Chern forest flora) differs essentially from the North-Asian subnemoral floristic complex by the direction of links. If the North-Asian flora is characterized by prevalence of the Western links, in Chern forests the Western and Eastern links are nearly

Table 3. Ratio of altitudinal-zonal geo-elements of flora in the chern forest belt of West Sayan (perhumid windward macroslope)

\begin{tabular}{|l|c|c|c|c|c|c|c|}
\hline Altitudinal-zonal group & $\begin{array}{c}\text { West } \\
\text { linked } \\
\text { species }\end{array}$ & $\begin{array}{c}\text { East } \\
\text { linked } \\
\text { species }\end{array}$ & $\begin{array}{c}\text { Auto- } \\
\text { chtonous } \\
\text { species }\end{array}$ & $\begin{array}{c}\text { Only } \\
\text { Western } \\
\text { species }\end{array}$ & $\begin{array}{c}\text { Only } \\
\text { Eastern } \\
\text { species }\end{array}$ & Total & $\begin{array}{c}\text { Subnemoral forest flora of } \\
\text { North-Asian hemiboreal fo- } \\
\text { rests (by Ermakov 2006) }\end{array}$ \\
\hline Nemoral & 11 & 11 & 37 & 24 & 28 & 17 & nemoral species $18 \%$ \\
\hline Dark-coniferous forest & 11 & 12 & 7 & 7 & 10 & 10 & taiga species $16 \%$ \\
\hline $\begin{array}{l}\text { Light-coniferous forest and } \\
\text { forest-steppe }\end{array}$ & 34,5 & 35 & 33 & 41 & 43 & 36 & hemiboreal species $40 \%$ \\
\hline $\begin{array}{l}\text { High-montanous and } \\
\text { montanous }\end{array}$ & 4,5 & 6,6 & 13 & 1 & 9 & 7 & Subalpine-forest species $6 \%$ \\
\hline Azonal & 39 & 35 & 10 & 27 & 10 & 30 & \\
\hline Total number of species & $\mathbf{3 8 4}$ & $\mathbf{3 6 2}$ & $\mathbf{7 3}$ & $\mathbf{1 0 9}$ & $\mathbf{8 7}$ & $\mathbf{5 4 4}$ & \\
\hline
\end{tabular}

Note: It is evident that though the number of species for chern and hemiboreal forest is almost three times different, the percentage correlation of zonal elements in the analyzed floras is very similar. It confirms the conclusion that they have common essence. 
equal. Moreover, when we consider florogenetic links of autochtonous elements of Chern forest flora, the Eastern links become more meaningful.

\section{CONCLUSION}

The Chern forest formations of coniferous (Pinus sibirica, Abies sibirica) and deciduous (mainly Populus tremula) species, with nemoral relicts in understory layers (shrubs, herbs, mosses and lichens) represent the most ancient variant of Siberian conifer forest ecosystems. They are unique in composition and posess features resembling some cold temperate forest ecosystems in the mountains of the Far East (Sikhote-Alin and Greater Khingan Mountains).

Floristic analysis of herb and moss layers in Chern forests proves that between the Sayan refugia and the eastern part of Asia there were quite close ties in historical epochs of the spread of the Turgay flora. The East Asian cool-temperate center of florogenesis essentially contributed in the Chern forest flora formation later, in the early Quaternary. An important feature of the Sayan refugia is the number of herb species with Eastern links. It is comparable with, or even exceeds the number of species having the Western links with Europe and the Mediterranean.

Composition of life forms with an increased role of cryptophytes and with a decreased role of chamaephytes confirms the conclusion on the antiquity of Chern forest flora, making it close to coniferous - deciduous broadleaved forest flora. The general role of phanerophytes is unusually low because the winter frosts impoverished the composition of forest-forming species in the periods of mountain glaciation. The peculiar composition of life forms in the species spectrum confirms the originality of not only Chern forests but of the whole spectrum of $\mathrm{ABC}$ in perhumid climate of the Sayans.

In our climatic ordination scheme, the Chern forests are placed exactly in the hemiboreal zone according to warmth regime. In other words, they are in the transition between the Boreal forests and Cold-Temperate mixed forests (with Betula spp., Pinus sylvestris, Larix sibirica). Populus tremula, the main deciduous tree species in this ecosystem, substitutes the "true temperate" broadleaved tree species in the absence of Tilia spp. and Quercus spp. within the Chern forest ABC.

Warmth limit and especially the great cold spels in the Quaternary period are the reasons for the present poor tree species composition. Besides, competition of Siberian fir as a strong dominant tree species and a thriving in herb layer of tall forbs and ferns lead to vulnerability and an unstable state of the Siberian pine population in the Chern forest. In the Holocene, the rapid decline of Pinus sibirica dominated forests in Sayan Mountains was continuing due to logging, windstorms and other disturbances. This makes urgent the problem of preserving the class of Chern rain-barrier forest ecosystems, which are unique to the Altai-Sayan Ecoregion and to Siberia as a whole.

\section{AKN OWLEGEMENTS}

We are greatful to our colleagues Victor Tsaregorodtsev and Nadya Andreeva for valuable technical support.

\section{LITERAT URE CITED}

Agakhanyants, O.E. 1986 Botanical geography of the USSR. Vyshaya Shkola, Minsk, 175 pp. (in Russian). [Агаханянц O.Е. 1986. Ботаническая география СССР. Минск: Вышейшая школа. 175 с.]

Anonymous 1966-1970. Reference book on the climate of the USSR. Vol. 1-4, issues 21-24. Gidrometeoizdat, Leningrad (in Russian). [Справочник по климату СССР 1966-1970. Т. 1-4, вып. 21-24. АенинграА: Наука.].

Baranov, V.I. \& M.N. Smirnov 1931. Fir taiga on the piedmonts of Altai. Permskoe knizhnoe izdatelstvo, Perm, 96 pp. (in Russian). [Баранов В.И., Смирнов М.Н. 1931. Пихтовая тайга предгорий Алтая. Пермь: Пермское книжное изАательство. 96 с.]

Cherepanov, S.K. 1995. Vascular plants of Russia and adjacent states (in the ranges of former USSR). Mir i semia, St-Peterburg, $992 \mathrm{pp}$. (in Russian). [Черепанов С.К. 1995. Сосудистые растения России и сопредельных государств (в пределах бывшего СССР). Санкт-Петербург: Мир и семья. 992 с.]

Ermakov, N.B. 1995. Classification of Siberian mountain subnemoral deciduous broad-leaved-dark coniferous and linden forests. In: Botanical researches in Siberia and Khazabstan, pp. 30-91, Altai State University, Barnaul (in Russian). [Ермаков Н.Б. 1995. КАассификация сиоирских горных суб̈неморальных мелколиственно-темнохвойных и Аиповых месов // Ботанические исследования Сио̆ири и Казахстана. Барнаул: А^тайский гос. университет. С. 30-91.]

Ermakov, N.B. 2006. Analysis of floristic composition of hemiboreal forests of Northern Asia. Turczaninowia 9(4): 5-92 (in Russian). [Ермаков Н.Б. 2006. Анализ флористического состава гемибореальных месов Северной Азии // Turczaniniwia. T. 9, № 4. С. 5-92.]

Gudoshnikov, S.V. 1986. Flora of leafy mosses in chern belt of South Siberian mountains and a problem of chern taiga origin. Izdatelstvo Tomskogo Universiteta, Tomsk, 192 pp. (in Russian). [Гудошников C.В. 1986. Фцора кистостебельных мхов черневого пояса южных гор Сибири и проблема происхожАения черневой тайги. Томск: ИзА-во Томского ун-та. 192 с.]

Holdridge, L.R. 1967. Life zone ecology. San Jose, 206 pp.

Ignatov, M.S., O.M. Afonina \& E.A. Ignatova 2006. Check-list of mosses of East Europe and North Asia. Arctoa 15: 1-130.

Isachenko, A.G., A.A. Shliapnikov \& O.D. Robozerova 1988. Landscapes of the USSR. Map. 1:4000000 scale. GUGK, Moscow. [Исаченко А.Г., ШАяпников А.А., Робозерова О.А. 1988. Аандшафты СССР. Карта. Масштаб 1:4000000. ГУГК, Москва.]

Ismailova, D.M. \& D.I. Nazimova 2010. Long-term dynamics of mixed fir-aspen forests in West Sayan (Altai-Sayan Ecoregion) In: Environmental Change in Siberia: Earth Observation, Field Studies and Modelling, (H. Balzter, ed.), pp. 37-51, Advances in Global Change Research, Springer Science+Business Media B.V.

Kamelin, R.V. 1998. Materials on the history of flora Asia (Altai Mountains Region). Izdatelstvo Altaiskogo Universiteta, Barnaul, 240 pp. (in Russian). [Камелин Р.В. 1998. Материалы по истории фморы Азии (ААтайская горная страна). Барнаул: ИзА-во Алтайского ун-та. 240 с.]

Krestov, P.V., D. Nazimova, N. Stepanov \& D. DellaSala 2010. Humidity-dependent forests of the Russian Far East, Inland Southern Siberia, and Korean Peninsula. In: Temperate and Boreal Rain Forest of the World: ecology and conservation. (D. DellaSala, ed.), pp. 222-234, Island Press, Washington.

Nazimova, D.I. 1975. Mountain dark-coniferous forests of West Sayan: Experience of ecological-coenotic classification. Nauka, Leningrad, 118 pp. (in Russian). [Назимова А.И. 1975. Горные темнохвойные меса Западного Саяна (опыт эколого-фитоценотической к^ассификации). А.: Наука. 118 с.]

Polikarpov, N.P., N.M. Tchebakova \& D.I. Nazimova 1986. Climate and mountain forests of Southern Siberia. Nauka, Novosibirsk, 225 pp. (in Russian). [Поликарпов Н.П., Чебакова Н.M., Назимова А.И. 1986. КАимат и горные Аеса Южной Сибири. Новосибирск: Наука. 225 с.] 
Polojii A.V. \& E.D. Krapivkina 1985. Relics of Tertiary broad-leaved forests in Siberian flora. Izdatelstvo Tomskogo Universiteta, Tomsk, 156 pp. (in Russian). [Положий А.В., Крапивкина Э.А. Реликты третичных широколиственных месов во флоре Сибири. Томск: ИзА-во Томского ун-та. 156 с.]

Red data book of Krasnoyarsk territory: The rare and Endangered Species of Wild Plants and Funguses. 2012. $2^{\text {nd }}$ edition revised and enlarged (N.V. Stepanov, ed.) Krasnoyarsk, vol. 2, 576 pp. (in Russian). [Красная книга Красноярского края. Т. 2: Редкие и находящиеся под угрозой исчезновения виды дикорастущих растений и грибов (отв. реА. Н.В. Степанов). Красноярск. 576 с.]

Smagin, V.N., S.A. Iljinskaya, D.I. Nazimova, I.F. Novoseltseva \& Yu.S. Cherednikova 1980. Forests types of mountains of Southern Siberia. Nauka, Novosibirsk. 333 pp. (in Russian). [Смагин В.Н., ИАьинская С.А., Назимова А.И., Новосельцева И.Ф., Чередникова Ю.С. Типы Аесов гор Южной Сибири. Новосиборск: Наука. 333 с.]

Shumilova, L.V. 1962. Botanical geography of Siberia. Izdatelstvo Tomskogo Universiteta, Tomsk, 439 pp. (in Russian). [Шумилова А.В. 1962. Ботаническая география Сибири. Томск: ИзА-во Томского ун-та. 439 с.]

Stepanov, N.V. 1994a. Florogenetic analyses of north-eastern part of the West Sayan. Izdatelstvo Krasnoyarskogo Universiteta, Krasnoyarsk, 108 pp. (in Russian). [Степанов Н.В. ФАорогенетический анализ северо-восточной части Западного Саяна. Красноярск: ИзА-во Красноярского ун-та. 1994.]

Stepanov, N.V. 1994b. A new species of the genus Waldsteinia (Rosaceae) from the West Sayan. Botanicheskii Zhurnal 79(9): 109-114 (in Russian). [Степанов Н.В. 1994. Новый виА рода Waldsteinia (Rosaceae) из Западного Саяна // Ботанический журнал. Т. 79, № 9. С. 109-114.]

Stepanov, N.V. 1994c. A new subspecies of Asplenium trichomanes (Aspleniaceae) from the West Sayan. Botanicheskii Zhurnal 79(10):
91-98 (in Russian). [Степанов Н.B. 1994. Новый подвиА Asplenium trichomanes (Aspleniaceae) из Западного Саяна // Ботанический журнал. Т. 79, № 10. С. 91-98.]

Stepanov, N.V. \& V.V. Stassova. 2011. About new taxon of the Adder's spear (Erytbronium - Liliaceae) genus from Western Sayan. Vestnik KrasGAU 8: 58-63. (in Russian). [Степанов H.B., B.B. Стасова. 2011. Новый таксон рода Erythronium (Liliaceae) из Западного Саяна // Вестник КрасГАУ, № 8. С. 58-63.]

Stepanov, N.V., I.E. Yamskikh , I.P. Philippova, O.E. Kryuchkova, E.V. Borisova \& V.K. Dmitrienko 2011. Atlas of plants, fungi and insects of chern belt in the West Sayan mountains. Izdatelstvo Sibirskogo Federalnogo Universiteta, Krasnoyarsk, 216 pp. (in Russian). [Степанов Н.В., Ямских И.Е., Филиппова И.П., Крючкова О.Е., Борисова Е.В., Амитриенко В.К. 2011. Атлас растений, грибоов и насекомых черневого пояса Западного Саяна. Красноярск: ИзА-во Сиб. федерал. ун-та. 216 с.]

Tchebakova, N.M. 1983. Radiation and heat balance in West Sayan. Geographya and prirodmyje resursy 4: 77-88 (in Russian). [Чебакова Н.M. 1983. Солнечная радиация и тепловой баланс в Западном Саяне // География и природные ресурсы. № 4. С. 77-88.]

Tchebakova, N.M. 2006. Possible transformations of plant cover of Siberia under different scenarious of climate change. Abstract of $\mathrm{PhD}$ thesis. Institute of forest SB RAS, Krasnoyarsk. 60 pp. (in Russian). [Чебакова Н.M. Возможная трансформация растительного покрова Сибири при различных сценариях климатических изменений. Автореф. Аисс. Аок. биол. наук. Институт Аеса СО РАН. Красноярск. 60 с.]

Urbanavichus, G.P. (compiler) 2010. A checklist of the lichen flora of Russia. Nauka, Saint-Petersburg, 194 pp. (in Russian) [Список михенофморы России / сост. Урбанавичус Г.П. 2010. Санкт-Петербург: Наука. 194 с.]

Walter, H. \& E. O. Box 1976. Global classification of natural terrestrial ecosystems. Vegetatio 32: 75-81. 